\title{
ENGLISH TRANSLATIONS OF THE QUR'ĀN AND THE ROLES OF WHY, BY WHOM, FOR WHOM AND HOW
}

\author{
Davut W. S. Peachy*
}

\begin{abstract}
The translation of a literary work from its original language to another requires not only great skill in both languages, but great knowledge of their literatures and cultures as well. A scripture, particularly the Qur'an, presents another, higher level of difficulty. Muslims hold that the Qur'an in any other language than the original Arabic is not the Qur'àn. Some scholars oppose Qur'anic translation per se. Others believe it is an integral part of the Prophet Muhammad's command to convey the Qur'anic message. Although Muslim translators understand their translations are not the Qur'an, this is why they must strive to transmit the message of the Qur'an to the best of their skills through their translations. Hundreds of editions have appeared in various languages, with the majority in English. By whom can the Qur'an be translated? A translator assumes he is the most qualified, skillful and dedicated in communicating with his target audience. They are the all-important ones for whom he must tailor his work. Once he has settled why, by whom and for whom, he can proceed to how. What style can he best use to reach his audience with the Qur'anic Message? What range of diction and level of discourse will he employ to bring his efforts into the cultural and social context of his readers? Can Islamic and Arabic terminology be conveyed without lengthy footnotes and commentary? The translator is responsible for making many difficult and crucial decisions which will affect the accuracy, clarity and acceptability of his work.
\end{abstract}

Key words: archaic, message, English Qur'anic translation, "scriptural style," target audience

Düzce University, Turkey.

(C) 2013 Al-Bayān Journal.

Published by Department of al-Qur'an and al-Hadith, Academy of Islamic Studies,

University of Malaya, 50603 Kuala Lumpur - Malaysia. 


\section{Introduction $^{1}$}

What is the purpose of any translation? What need is met by a Qur'anic translation? A translation is required when a target audience (TA) wants or needs to get information or a message contained in a medium that they do not understand, i.e. when the original language cannot convey the communication, or when an individual or a group wants to transmit information or a message to a TA whose medium of understanding is different than that of the original. To extend this argument, when a translation does not convey the information or message because the style and phrasing of the conveyance is different than the style and phrasing that the TA can process, then that translation is useless. If one wants to deliver a message to a TA in contemporary Spain, does one deliver it in the dialect of Mexico or South America? or yet in Ladino, the archaic $15^{\text {th }}$ century Spanish dialect spoken now only by a small Jewish community in Istanbul? Nowadays, one would not choose to convert data from a 51/4-inch floppy disk to a 31/2-inch floppy disk, a similarly obsolete and inappropriate medium, but rather to transfer it using one of the more modern options. Thus, the complexity, dialect and style of the target language must depend on that of the TA, not the audience of a millennium, a century or even decades ago. In the case of the Qur'ān, the original language has not changed in more than fourteen centuries, at least in the belief of Muslims. An official text prepared by companions of Muhammad ibn 'Abdullāh (570-632) and seven of the accepted readings have been in existence since the reign of the third Caliph, 'Uthmān ibn 'Affān (577-656).

The message of Islam is meant to be universal. However, the original and only medium of that message acceptable to most of its billion and a half believers is a language most people of the world do not understand. The original audience of the scripture understood the "clear Arabic" very well, even if they did not converse in it.

This paper had its beginning in a public seminar, "The Problem of the Audience in Qur'anic Translation," the author held at the then Institute of Languages and Translation, later the College of Languages and Translation, King Saud University, on 24 April 1994. This topic was refocused and developed for presentation at the First International Symposium on Rethinking the Qur'ān held in Ankara, Turkey, 3-5 May 2013, under the title, "The Roles of Why, By Whom, For Whom and How in Qur'anic Translation.” 
That Arabic had a special, high style, yet Allah apparently expected the message to be understood by all who spoke the languages and dialects of the Arabic family as mother tongues, the Arabs of the Arabian Peninsula and the Levant. ${ }^{2}$ Those Arabic tongues were largely oral media, and most of their speakers were illiterate. The Prophet himself could neither read nor write. It is clear from the Qur'ān that Allah did not expect full comprehension of its reading or recitation. He instituted a first reader, i.e. a model reciter and interpreter in the person of His final Messenger.

\section{Why Translate the Qur'ān?}

The two foundations of Islam, the Qur'àn and the Sunnah of the Prophet Muhammad form the bases of, and provide the primary driving force for, all Qur'anic translation. The Qur'ān has twentyfive verses that contain the words meaning "message", "messages" and "delivery". The first such verse is quite clear in the matter: "Messenger, make known what has been sent down to you from your Lord, for if you do not do it, you will not have delivered His message...." The second such verse implies that the message is to be delivered to mankind: "Obey God and obey the Messenger, and beware! But if you turn away, then know that the duty of Our Messenger is only plain delivery (of the message)." ${ }^{4}$ It can be inferred from one of the most commonly recited chapters of the Qur'ān that it is the duty of every believer to pass on the message: "By Time, Man indeed is at a loss, except those who have believed, done good deeds, urged one another to truth and urged one another to patience." Towards the end of his Farewell Sermon to more than 100,000 pilgrims, the Prophet Muhammad explicitly passed that responsibility on to his followers: "Indeed I've left among you the Book of God. If you follow it, you shall never go astray.... Let those who've witnessed (it)

\footnotetext{
2 See Michael Zwettler, The Oral Traditions of Classical Arabic Poetry: Its Character and Implications (Columbus, Ohio, 1978), especially Chapter Three, "The Classical 'Arabîya as the Language of an Oral Poetry," 98-184.

3 The Qur'ān, 5:67. All translations come from the authors' translation, The Qur'ann: The Final Book of God (Qassim, Kingdom of Saudi Arabia: World Assembly of Muslim Youth, 2012), translated by Daoud W. S. Peachy and Maneh H. Al-Johani.

The Qur'àn, 5:92.

The Qur'ān, 103:1-3.
} 
take it to those absent, for many (of them) may mind it better than those who've already heard it. And if they ask you about me, what are you going to say?" They answered, "We witness that you fulfilled the trust, lived up to the prophethood and advised and guided well." The Prophet lifted his forefinger to the sky and then to the people and said, "Lord, witness it. Lord, witness it."

The Qur'anic message came in a qur'ān, a recitation, of clear Arabic, but its audience was the entirety of man and jinn for all time until the Day of Resurrection and the Day of Judgment. About 7,000 different languages are spoken today by some $6,000,000,000$ souls. The number of dead languages may range into the tens of thousands. With each human normally understanding speech in his own tongue alone, and no more than 300,000,000 speaking or reading any form of Arabic, it is not surprising that there is evidence of Quranic translation beginning from the time of the Prophet Muhammad. It was reported that Salmān al-Fārisī (d. circa 657), a Companion of the Prophet, translated at least the first chapter of the Qur'ān into Persian for those who knew no Arabic. ${ }^{7}$ In his Jämi' alBayān, it was al-Ṭabarī (840-923) who prepared the first complete translation and commentary into Persian in the late $10^{\text {th }}$ century, and a Turkic version of that was produced almost simultaneously. ${ }^{8}$ Even

Many versions of the Farewell Sermon to be found in English translations of the major hadith collections and biographies of the Prophet are partial and may differ in what they leave out. Two reliable sources are Sahị huslim translated by Abdul Hamīd Siddīqī (Beirut, Dār Al-Arabia, undated) Hadith No. 2803, Vol. 2, 612-617. In the Arabic publication with the English translation by Muhammad Muhsin Khan, The Translation of the Meanings of Sahih Al-Bukhari, 9 vols. (Al-Riyadh: Maktabatu 'l-Riyādhi 'l-Hadīthah, 1402 H/1981 CE) Vol. 2, 460, Chap. 132, Nos. 795-798, it is Bukhārī who relates the command for those present to convey the message to those not present.

Like others, Hidayet Aydar \& Necmettin Gökkir in their "Discussions on the Language of Prayer in Turkey: A Modern Version of the Classical Debate," Turkish Studies, Vol. 8, No. 1 (2007) 121-136, cite Abū Zakariyyā Yahyā an-Nawāwī, Al-Majmū' Sharh al-Muhadhdhab. See also Husain, Muḥammad Bahā al-dīn, Tarjumah al-Qur'ān alKarīm: Ḥukamā wa Ārā̄ al-Ulamā fîhā,” [Translation of the Noble Qur'ān: Rulings and Opinions of the Ulema about It], Dirāsāt al-Jämi'ah al-Islämiyah al-Alamìyah (Chittagong/Thailand: Al-Jāmi'ah al-Islāmiyah al-'Alamīyah, 2006), Vol. III, 133144.

8 See Hartmut Bobzin's “Translations of the Qur'ān,” Encyclopaedia of the Qur'ān, Vol. 5 (Leiden-Boston: Brill, 2006), 341. 
very early in Islamic history, Arab Muslims needed commentaries to explain the meanings of Qur'anic words and phrases that were not in their dialects or that had passed out of usage.

All speakers or comprehenders of that "Clear Arabic" ('Arabìyu'Mubin) were the original TA for the Qur'anic message. By the time of the death of Muhammad in $632 \mathrm{CE}$, the Arabian Peninsula comprised a new Muslim state with its brain at Medina and its heart in Mecca. However, soon afterwards, during the reigns of the four companion successors, the Rightly Guided Caliphs, that state had grown into an empire, and included peoples whose mother tongues were not Arabic, and most of whom were not even Semitic. Even the Arabic languages and dialects, which had not been uniform before, became that much more diverse under the influence of the then dominant international languages, the most important of which were Aramaic, Classical Greek and Old Persian. Along with these languages came their strong literary traditions and alien cultures.

Whether or not the idiom of the translation is current or obsolete, with the translation from one language to another comes an inevitable, if unwanted, change in meaning. The literary tools of Qur'anic Arabic are not fully available in other languages, and when those that are available are employed, they do not always have the same effect as such devices in Qur'anic Arabic. Words alone are difficult enough to translate into another language, but inflection, rhyme, alliteration, word order, ellipsis, and other aspects of grammar and style are usually more difficult, often impossible, to render. Each new, would-be translator makes the effort to do a better job than those of his predecessors whom he finds inadequate in some important way.

Many Muslims have claimed that translation of the Qur'ān is impossible. Many of the translators, both Muslim and non-Muslim alike, who have tried to give the sense of the Qur'ān in English have admitted that a translation equal to the Qur'ān in quality and impact is impossible. Nevertheless, new translations continue to be published. The paradox is only apparent. They are really admitting that the result of their efforts to translate the Qur'ann are not and can never be the Qur'ān. Muslims hold it to be inimitable, miraculous. 
The Qur'ān challenged doubters to produce a single chapter like any of its chapters, ${ }^{9}$ and more than 1,400 years later, no one of note has tried, let alone succeeded, in doing so.

\section{History of Qur'anic Translation in English}

In 1143, Robert of Ketton (fl. 1136-1157) prepared the first Western, Latin translation of the Qurān. It appeared in print in 1543. ${ }^{10}$ While the first partial, printed English translation appeared sometime around 1515, ${ }^{11}$ André du Ryer (d. 1660) used Robert of Ketton's Latin translation for his complete French translation in 1647. ${ }^{12}$ The chaplain to the English King Charles I (1600-1649), Alexander Ross (c. 1590-1654) knew no Arabic, and his French was weak, ${ }^{13}$ but his translation of 1649 from du Ryer's French, was the first complete one to appear in English. ${ }^{14}$ One by George Sale (1697-1736) followed in $1734,{ }^{15}$ and another by J. M. Rodwell (1808-1900) came out in $1861 .{ }^{16}$ Sale's rendering remained the

9 "And if you are in doubt about what We have revealed to Our slave (Muhammad), then produce just a chapter like it, and call your witnesses besides God if you are true." (The Qur'àn, 2:23) Cf. 10:38 cited above.

10 Machvmetis saracenvrum principus, eius'qve svccessorvm vitae, ac doctrina, ipséqve Alcoran..., Robertus Ketenensis and Hermannus Dalmata, 5 vols. (Basil 1543) as cited by İsmet Binark and Halit Eren, World Bibliography of Translations of the Meanings of the Holy Qur'an: Printed Translations 1515-1980, edited by Ekmeleddin İhsanoğlu (İstanbul: The Research Center for Islamic History, Art and Culture, 1406/1986), 285.

11 The work is anonymous and is catalogued so: Here begynneth a lytell treatyse of the turkes law called Alcoran. And also it speketh of Machamet to Nygromancer (London: 1515 ?) in Binark and Eren, 152.

12 Saeed, Abdullah. The Qur'ān: An Introduction (London \& New York: Routledge, 2008).

13 According to A.R. Kidwai, "As to the quality of the translation itself, Zwemer's remark is quite illuminating: 'He (Ross) was utterly unacquainted with Arabic, and not a thorough French scholar; therefore his translation is faulty in the extreme'. Zwemer, S.M., Muslim World, V, (1915), 250," "English Translations of the Holy Qur'ān An Annotated Bibliography," Anti-Ahmadiyya Movement in Islam (October 2000), accessed 15 October 2013: <http://alhafeez.org/rashid/qtranslate.html./>

14 The Alcoran of Mahomet, translated by Alexander Ross (London, 1649), cited by Binark and Eren, 111.

15 The Koran translated by George Sale, (London, 1734), cited by Binark and Eren, 115.

16 The Koran translated by John Meadows Rodwell (Hertford/London, 1861), cited by 
standard until a popular, affordable edition of Rodwell's was printed in 1909. ${ }^{17}$ Rodwell's translation is still in print today. All of these Western translations were done to expose and refute Islam and the Qur'ān.

In 1905, Mohammad Abdul Hakim Khan from India published the first English translation by a non-Westerner. ${ }^{18}$ In 1917, the Ahmadiyyah sect published an edition of the translation of Maulana Muhammad Ali (1874-1951), with the Arabic text, commentary and footnotes. ${ }^{19}$ This was an improvement on the previous translations by Englishmen and had a great influence on subsequent translations. The non-Muslim A. J. Arberry (1905-1969) did not credit Muhammad Ali's work as having any influence upon his own effort of $1955 .{ }^{20}$ He did, however, acknowledge the importance of Mohammed Marmaduke Pickthall (1875-1936), whose translation was first published in 1930. ${ }^{21}$ Abdullah Yusuf Ali (1872-1953), whose translation first appeared in 1934, considered Pickthall's effort to be "literal" but without enough elucidating notes to clarify the meanings. ${ }^{22}$ Pickthall's translation has been significant not only because his was the first done by a Western convert to Islam, but also

Binark and Eren, 103.

17 The Koran translated by John Meadows Rodwell, ed. with an introduction by G. Margouliouth (London, 1909), cited by Binark and Eren, 103.

18 The Holy Qur'ān translated by Mohammad Abdul Hakim Khan (Karnal, 1905), cited by Binark and Eren, 87-88. A.R. Kidwai has convincingly disputed his credentials as the first Muslim translator, showing circumstantial and textual evidence of his being a Qadiyani/Ahmadi. Kidwai, “A.R. Mohammad Abdul Hakim Khan's The Holy Quran (1905): The First Muslim or the First Qadiyani English Translation?” Insights 02:1 (Autumn, 2009) 57-72. Accessed 25 October 2013: <http://ehis.ebscohost.com/ ehost/pdfviewer/pdfviewer?sid=896cb4bb-2d55-4b39-91 ef-7ce5140fdfe 5\%40sessio nmgr111\&vid=1\&hid=105/>. Information on the birth and death dates of Abdul Hakim Khan are not available.

19 The Holy Qur'ān translated by Maulana Muhammad Ali (Woking/London, 1917), cited by Binark and Eren, 88.

20 The Koran Interpreted translated by Arthur J. Arberry in 2 Vols. (London, 1955), cited in Binark and Eren, 76-77, and The Koran Interpreted translated by Arthur J. Arberry 2 Vols. in $18^{\text {th }}$ Printing (New York: 1979), 20-22.

21 The Meaning of the Glorious Koran translated by Mohammed Marmaduke Pickthall (London, 1930), cited in Binark and Eren, 97.

22 The Holy Qur'an translated by Abdullah Yusuf Ali (Lahore 1934-1937), cited in Binark and Eren, 65. THE HOLY QUR'AN: Text, Translation and Commentary (Brentwood, Maryland, U.S.A.: Amana Corp., 1983), xiii.” 
because he was a highly-educated, native speaker and respected writer of English. His translation remains in print in many editions, and it has inspired and formed the basis for many following ones, including that of this translator, which is discussed below. The translations of both Pickthall and Yusuf Ali were apparently influenced by that of Muhammad Ali, and so that of Arberry and many others have been indirectly influenced by that of Muhammad Ali. While the acknowledgement of such influence should not be a problem for any orientalist or other non-Muslim, it is a sensitive subject, at least, for Sunni Muslims.

The translation of Yusuf Ali was judged by the Presidency of Islamic Research, Call and Guidance of the Kingdom of Saudi Arabia to be elegant and close to the meaning of the text. Consequently, a revised edition of his work was designated as the official English translation of the Holy Qur'ān in Saudi Arabia. Its elegance of style and high formal diction was obviously intended for a scholarly and educated English-speaking audience. ${ }^{23}$ This edition was replaced as their official version by that of Al-Hilālī (1893-1987) and Muhsin Khān (1927-) in 1996. ${ }^{24}$ While their joint effort is in quite a different style and has quite a different purpose, it is obvious that their translation, still distributed free by the government of the Kingdom of Saudi Arabia, was based on that of Yusuf Ali.

In 1937, Richard Bell (1876-1952) published The Qur'än Translated, with a critical re-arrangement of the Surahs. As the title indicates he rearranged the order of the material, and so Muslims do not refer much to his effort, let alone rely on it. He has continued to be influential among orientalists, and he has not been the last to devalue what almost all Muslims hold as the truth, that the order was revealed to the Messenger Muhammad by Allah through the Angel Gabriel and should be interpreted in that way. ${ }^{25}$ The first edition of the popular translation of N.J. Dawood (1927-) in 1956

23 The Holy Qur-an translated by Abdullah Yusuf Ali, ed. by the King Fahd Holy Qur-ān Printing Complex/KFHQPC (Madinah: KFHQPC, 1410/1989-90), vi.

24 The Noble Qur'ān translated by Muhammad Taqi-ud-Dīn al-Hilāli and Muhammad Muhssin Khān, ed. by King Fahd Complex for the Printing of the Holy Qurān/ KFCPHQ (Madinah: KFHQPC, 1424/2003-4).

25 The Qur'än. Translated, with a critical re-arrangement of the Surahs by Richard Bell, 2 Vols. (Edinburgh: T. \& T. Clark, 1937). 
used a chronological order. ${ }^{26}$ Both Bell's and Dawood's efforts are discussed again below. Like Dawood, T.B. Irving (1914-2002) prepared a translation in contemporary, understandable English. ${ }^{27}$ While Dawood remained a Jew, Irving was a Canadian convert to Islam. His translation in North American English continues to be used by Muslims in America despite the free Saudi distribution of the Hilālī and Muhsin Khan translation. Irving's translation is also mentioned again below along with Muhammad Akbar's translation of the commentary of Maudūīi (1903-1979) ${ }^{28}$ and this translator's 2012 effort.

The advances in the printing press in the $18^{\text {th }}$ and $19^{\text {th }}$ centuries and the spread of literacy in the $20^{\text {th }}$ century undoubtedly contributed to the worldwide Qur'anic translation phenomenon. The success of British colonialism in the $19^{\text {th }}$ and $20^{\text {th }}$ centuries as well as the growth of American imperialism in the $20^{\text {th }}$ and $21^{\text {st }}$ centuries has made English the lingua franca of the world and the language of choice for translators.

From 1515 through 1980, a total of 2,672 partial and complete editions of the Qur'àn were published. Of that number, 427 were in English and for the 296 complete editions in English, there were thirty-two different translators. Forty-eight different writers also produced new, partial translations, which made a total of eighty English translators by 1980. Binark and Eren, in their study on printed translations published through 1980, revealed that only four complete English translations existed before 1900. ${ }^{29}$ A great many new English translations of the Qur'ān appeared in the $20^{\text {th }}$ century. By 1980, there were sixty-one more. Binark and Eren noted that, while translations existed in sixty-five languages, most editions and new translations were in English. It is estimated that in the decades since 1980, about fifty more English translations and new editions

\footnotetext{
26 The Koran translated by N. J. Dawood, (Harmondsworth, Middlesex, England: Penguin Books Ltd., 1956), $3^{\text {rd }}$ Revised Ed. (London, 1968).

27 The Qur'ann: The First American Version translated by T. B. Irving (Brattleboro, Vermont, U.S.A.: Amana Books, 1985).

28 The Meaning of the Quran by S. Abul A'lā Maudūdī, translated by Muhammad Akbar and edited by A. A. Kamal, $4^{\text {th }}$ to $11^{\text {th }}$ Eds., 16 Vols. in 6 (Lahore: Islamic Publications (Pvt.) LTD, 1990-1).

29 Binark and Eren, XII.
} 
have been published by more than twenty different translators. The vast majority of publications in all languages have been produced in the $20^{\text {th }}$ and $21^{\text {st }}$ centuries. The greatest number of these translations and new editions are in English, and the rate of the appearance of new English translations is constantly accelerating. ${ }^{30}$

The personal motivations of translators and the quality of their translations are varied. Yet the common factor in all these subsequent translations, particularly in all English translations up to the present, has been the perception that preceding translations have not measured up to the standard of the original, the Qur'an. Previous translations have been considered weak, inaccurate, biased or antiquated, and lately, too simple, too complex, too literal or too liberal. Mohammed Marmaduke Pickthall, the first Muslim from the West to translate the Qur'ān, referred to the Revelation as "that inimitable symphony, the very sounds of which move men to tears and ecstasy." ${ }^{31}$ Is it then no wonder that each new translation has failed to measure up to that noble book?

There is another, important factor underlying the dissatisfaction with existing translations. While the Arabic of the Qur'an has remained the same, preserved by millions of its memorizers and hundreds of millions of its copies, every language used to translate it has undergone great change. The Latin used for the first manuscript translation is now virtually dead. The most popular language for Qur'anic translation, English, did not exist in a form recognizable as English at the time the Qur'an was revealed in the $7^{\text {th }}$ century. The language of the first complete English translation in the $17^{\text {th }}$ century is not one that most can understand today. Even translations published in the early $20^{\text {th }}$ century are now difficult to understand for many whose mother tongue is English. While the language of the Qur'ān is fixed forever, translations must be continually redone in the current idiom of the group that is to read it (the TA).

\footnotetext{
30 Four English translations that have recently appeared are Thomas Cleary's The Qur'ann: A New Translation (Chicago: Starlatch Press, 2004), M. A. S. Abdel Heleem's The Qur'ān (New York: Oxford, 2004 \& 2005), Laleh Bakhtiar's The Sublime Quran (Chicago: Kazi Publications, 2007), and Niyazi Kahveci's English Translation of alQur'ān al-Karìm (Ankara: Akasya Kitap, 2007).

31 Pickthall, $1^{\text {st }}$ page of the "Translator's Forward" in many editions.
} 


\section{Examples and Comparisons, Past and Present-How was it done?}

By looking at the last four verses of the opening chapter, the "Fätiha", the style of the Yusuf Ali translation can be analyzed:

5. Thee do we worship,

And Thine aid we seek.

6. Show us the straight way,

7. The way of those on whom

Thou hast bestowed Thy Grace,

Those whose (portion)

Is not wrath,

And who go not astray. ${ }^{32}$

The above verses employ four archaic, i.e. obsolete, words: thee for you, thine for your, thou for you and hast for have. ${ }^{33}$ In the fifth verse, we see two abnormal inversions of standard English syntax: "Thee do we worship" instead of "We worship Thee", and "Thine aid we seek" instead of "We seek Thine aid." In the first line of the seventh verse, there is an example of formal style, "on whom." and in the second line of the same verse, we see an example of formal or high diction, "bestowed Thy Grace." These lines could be rendered in simple clear English as something like "those You have favored." In the last line of the seventh verse, we see another archaic grammatical form: "and who go not astray" instead of "and who do not go astray."

The Yusuf Ali text can now be compared to alternative versions of the complete "Fätihah":

$$
\text { Yusuf Ali -1934) }
$$

1. In the name of God, Most Gracious, Most Merciful.

2. Praise be to God, The Cherisher and Sustainer of the Worlds;

32 The Holy Qur'ān, Abdullah Yusuf Ali, (Reprinted in Brentwood, Maryland, U.S.A.: Amana Corp., 1983), 14-15.

33 This author noted the phenomenon of archaic pronouns and verb forms in his seminar in 1994 (See fn. 1.). Jane Dammen McAuliffe also noted it in her "Introduction" to The Cambridge Companion to the Qur'ann, edited by McAuliffe, Jane Dammen (Cambridge, U.K.: Cambridge University Press, 2006), 16. 
3. Most Gracious, Most Merciful;

4. Master of the Day of Judgment.

5. Thee do we worship, And Thine aid we seek.

6. Show us the straight way,

7. The way of those on whom Thou hast bestowed Thy

Grace, Those whose (portion), Is not wrath, And who go not astray. ${ }^{34}$

(George Sale - 1734)

\section{IN THE NAME OF THE MOST MERCIFUL GOD}

Praise be to God, the Lord of all creatures; the most merciful, the king of the day of judgment. Thee do we worship, and of thee do we beg assistance. Direct us in the right way, in the way of those to whom thou hast been gracious; not of those against whom thou art incensed, nor of those who go astray. ${ }^{35}$

$$
\text { (J. M. Rodwell - 1861) }
$$

In the Name of God, the Compassionate, the Merciful

Praise be to God, Lord of the worlds!

The compassionate, the merciful!

King on the day of reckoning!

Thee only do we worship, and to Thee do we cry for help.

Guide Thou us on the straight path, The path of those to whom Thou hast been gracious;with whom thou art not angry, and who go not astray. ${ }^{36}$

$$
\text { (M. Muhammad Ali - 1917) }
$$

In the name of Allāh, the Beneficent, the Merciful.

1. Praise be to Allāh, the Lord of the worlds,

$34 \quad$ Abdullah Yusuf Ali (1983), 14-15.

35 The Korân translated by George Sale (London, 1734), 1893 Ed. with an introduction by Edward Denison Ross (London \& New York: Frederick Warne and Co. LTD., 1949), 1.

36 The Koran translated by J. M. Rodwell, forward and introduction by Alan Jones (London: J.M. Dent \& Vermont: Charles E. Tuttle, 1994), 3. 
2. The Beneficent, the Merciful,

3. Master of the day of Requital.

4. Thee do we serve and Thee do we beseech for help.

5. Guide us on the right path,

6. The path of those upon whom Thou hast bestowed favours,

7. Not those upon whom wrath is brought down, Nor those who go astray. ${ }^{37}$

$$
\text { (Mohammed M. Pickthall - 1930) }
$$

In the name of Allah, the Beneficent, the Merciful.

1. Praise be to Allah, Lord of the Worlds,

2. The Beneficent, The Merciful.

3. Owner of the Day of Judgment,

4. Thee (alone) we worship; Thee (alone) we ask for help.

5. Show us the straight path,

6. The path of those whom Thou hast favoured;

7. Not (the path) of those who earn Thine anger nor of those who go astray. ${ }^{38}$

$$
\text { (Richard Bell - 1937) }
$$

In the Name of Allah, the Merciful, the Compassionate.

1. Praise belongs to Allah, the Lord of the worlds,

2. The Merciful, the Compassionate.

3. Wielder of the Day of Judgment.

4. Thee do we serve, and on Thee do we call for help;

5. Guide us the straight path,

6. The path of those upon whom Thou hast bestowed good,

7. Not (that) of those upon whom anger falls, or those who go astray. ${ }^{39}$

The Holy Qur'än: Arabic Text, English Translation and Commentary translated by Maulana Muhammad Ali (Woking/London, 1917), $6^{\text {th }}$ Ed. (Lahore, 1973), 3.

38 The Meaning of the Glorious Koran translated by Mohammed Marmaduke William Pickthall (London: George Allen and Unwin, Ltd., 1930, New York: Mentor Books, circa 1965), 31. 


$$
\text { (A .J. Arberry - 1955) }
$$

In the Name of God, the Merciful, the Compassionate Praise belongs to God, the Lord of all Being, the All-merciful, the All-compassionate, the Master of the Day of Doom.

5 Thee only we serve; to Thee alone we pray for succour.

Guide us in the straight path, the path of those whom Thou hast blessed, not of those against whom Thou are wrathful, nor of those who are astray. ${ }^{40}$

\section{(Muhammad Akbar - 1967)}

In the name of Allah, the Compassionate, the Merciful.

1-3 Praise is only for Allah, the Lord of the Universe, the All-Compassionate, the All-Merciful, the Master of the Day of Judgment.

4-7 Thee alone we worship and to Thee alone we pray for help. Show us the straight way, the way of those whom Thou hast blessed; who have not incurred Thy wrath, nor gone astray. ${ }^{41}$

It is apparent that Yusuf Ali was not the only one, however, to employ formal high diction and an obsolete style in his translation. There is continuity from Sale to Akbar in the use of the secondperson-singular personal pronouns with the corresponding secondpersonal forms of the verbs of the subject pronouns. There is a succession of inversions of the subjects and the objects of sentences. The typically archaic "scriptural style" used in translation of religious texts, a genre that persists up to the present day, can be seen in all of these examples. In 1980, the highly respected, Muhammad Assad stated in the introduction to his translation:

\section{AS REGARDS the style of my translation, I have}

Arberry, 29.

Maudūdī and Akbar, Vol. 1, 40. A new translation of Maudūdì's commentary is being prepared by Zafar Ishaq Ansari. Volumes 1-9/Sürahs 1-37 (Leiscester, 1988-2009) have already been published by The Islamic Foundation of Leicester, UK, and Vol. 10 through Sūrah 46 is expected in December 2013. 
consciously avoided using unnecessary archaisms, which would only tend to obscure the meaning of the Qur'àn to the contemporary reader. On the other hand, I did not see any necessity of rendering the Qur'anic phrases into a deliberately 'modern' idiom, which would conflict with the spirit of the Arabic original and jar upon any ear attuned to the solemnity inherent in the concept of revelation. ${ }^{42}$

Evidently, the spirit of the original for him, too, required the necessary archaisms of the second-person-singular pronouns and inversions:

(5) Thee alone do we worship; and unto Thee alone do we turn for aid.

(6) Guide us the straight way-

(7) the way of those upon whom Thou has bestowed

Thy blessings, not of those who have been condemned

(by Thee), nor of those who go astray! ${ }^{43}$

There are a few modern exceptions to expression in this style, two examples being the works of N. J. Dawood and T. B. Irving, whose "Fätihah" translations appear below for comparison. With Dawood, we finally see a departure from the use of the second-person-singular pronouns and verbs, but both he and Irving do retain the inversions of subjects and objects and a formal style.

$$
\text { (N. J. Dawood - 1956) }
$$

INTHENAMEOFALLAHTHECOMPASSIONATE THE MERCIFUL

Praise be to Allah, Lord of the Creation,

The Compassionate, the Merciful,

King of Judgment-day!

You alone we worship, and to You alone we pray for help.

Guide us to the straight path,

\footnotetext{
42 The Message of the Qur'ann translated by Muhammad Asad (Gibraltar: Andalus Press, 1980), reprinted (Lahore, Pakistan: Maktaba Jawahar ul uloom, circa 1982), viii. 43 Ibid., 2.
} 
The path of those whom You have favoured, Not of those who have incurred Your wrath, Nor of those who have gone astray. ${ }^{44}$

$$
\text { (T. B. Irving - 1985) }
$$

In the name of God, the Mercy-giving, the Merciful!

*Praise be to God, ${ }^{*}$ Lord of the Universe,

*the Mercy-giving, the Merciful!

*Ruler on the Day for Repayment!

**You do we worship and You do we call on for help.

* Guide us along the Straight Road,

*the road of those whom You have favored,

with whom You are not angry,

nor who are lost! ${ }^{45}$

The final and newest example of a contemporary rendering of the message of the Glorious Qurān is the effort of this author and his late colleague Dr. Maneh Al-Johani.

(D. W. S. Peachy \& M. H. Al-Johani - 2012)

In the name of God, the Gracious, the Merciful

1. Praise belongs to God, the Lord of All Beings,

2. The Gracious, the Merciful.

3. Master of the Day of Judgment,

4. It is You we worship, and it is You we ask for help.

5. Show us the straight path,

6. The path of those whom You have favored,

7. Not (the path) of those who have earned Your anger nor of those who are astray. ${ }^{46}$

It is not only a few, new Qur'anic translators who have abandoned the traditional English "scriptural style." Here the $23^{\text {rd }}$ Psalm of David is given in the traditional King James Version of the Bible, the archetype of the genre, a translation of a religious work in the English "scriptural style," alongside a recent, modern version:

\footnotetext{
44 Dawood, 15.

45 Irving, 1.

46 Peachy and Al-Johani, 4.
} 


\section{THE KING JAMES VERSION-1611}

1. The Lord is my shepherd; I shall not want.

2. He maketh me to lie down in green pastures: he leadeth me beside the still waters.

3. He restoreth my soul: he leadeth me in the paths of righteousness for his name's sake.

4. Yea, though I walk through the valley of the shadow of death, I will fear no evil: for thou art with me; thy rod and thy staff they comfort me.

5. Thou preparest a table before me in the presence of mine enemies: thou anointest my head with oil; my cup runneth over.

6. Surely goodness and mercy shall follow me all the days of my life: and I will dwell in the house of the Lord for ever. ${ }^{47}$

\section{THE NEW REVISED STANDARD VERSION $-1989$}

1. The Lord is my shepherd, I shall not want.

2. He makes me lie down in green pastures; he leads me beside still waters;

3. he restores my soul. He leads me in right paths for his name's sake.

4. Even though I walk through the darkest valley, I fear no evil; for you are with me; your rod and your staff-they comfort me.

5. You prepare a table before me in the presence of my enemies; you anoint my head with oil; my cup overflows.

6. Surely goodness and mercy shall follow me all the days of my life, and I shall dwell in the house of the Lord my whole life long. ${ }^{48}$

The Holy Bible, Authorized King James Version (London: Oxford University Press, circa 1954), 728-9.

48 The Holy Bible, New Standard Version, accessed 19/02/2013. <http://www. sundayschoolverse.co.uk/BIBLE/NRSV/Psalms/Psalm23NRSV.htm/> 
The King James Version of the Bible was first published in 1611, and this edition swept aside all earlier English translations. Even today, many Christians still stubbornly cling to that traditional translation, despite the fact that the scholarship on which it was based is now hopelessly out of date, and its language is antiquated and often incomprehensible to modern readers. It is written in a beautiful, elegant and poetic style, appealing to the aesthetics of the highly-educated English-speaking elite, but undoubtedly some of the message has been lost in the process. Its influence seems to have dominated most of the efforts of Muslim scholars, as can be seen in the above examples of the "Fätihah".

Why is it so difficult to break away from this traditional style? Why can a translator not keep the language as simple, as free of interpolations and as unburdened by footnotes as possible? Is it necessary to choose obtain instead of get, distribute instead of give out, sublime instead of great? Is it truly better to convey in twenty words that which the Qur'àn conveys in ten? In attempting to convey the meaning and style of the "Fätihah", is it really more worthy to say "Thee do we worship" instead of "It is You we worship"? This brings us back to the question: Why does one translate? to please oneself or to deliver the message? Which is more likely to please the Lord God if one is Muslim?

\section{The Target Audience-For Whom?}

Thus, we can assume that Yusuf Ali's translation was aimed at an audience who could understand the archaic style of English preserved in the King James Version of the Bible. Dawood made an effort to accommodate a more contemporary British audience. However, like his predecessors, he wanted to "convey both the meaning and the rhetorical grandeur of the original" in a practical manner. Unfortunately, he took it upon himself to rearrange God's order, rectifying the arrangement of chapter and verse of the Qur'ān. In order to spare the uninitiated reader "such mundane chapters as 'The Cow' and 'Women'," 99 he placed them at the end of the work.

Irving kept to the Qur'anic order and aimed his work at "a

49 Dawood, 11. 
new generation of English-speaking Muslims," ${ }^{50}$ a generation cut off from their roots in Arabic and traditional Islamic culture. He claimed, "I have tried to find the simplest word so that the Muslim child can understand it easily, and feel strengthened thereby. It is also intended for the pious non-Muslim who is not already tied in theology of some sort..." 51 These words clearly indicate his TA: North American Muslims with at least a predisposition to Islam and whose command of English is limited to that of a North American child, as well as pious, open-minded non-Muslims.

Clearly Irving and Dawood tried to broaden the audience to include non-scholarly readers in Britain and North America. Ironically, it was Yusuf Ali who pointed out in 1934: "The English language being widely spread over the world, many people interested in Islam will get their ideas of the Qur-aan from English translations." And he goes on more pointedly, "The Indian educational system has enthroned English as the common language of culture for a population of 350 millions. The most educated of its 80 million Muslims - unless they know Arabic_-look to English as the most cultivated medium of expression. Their non-Muslim countrymen judge-usually misjudge - their religion by the material which is available to them in English." 52

Irving made an admittedly tentative start in the broadening of a target audience, and more attempts along the lines of his work need to be developed. Unsophisticated native speakers of English and those who know English as a second, third, or foreign language represent a great potential target audience. The recent Peachy/AlJohani translation attempted to bridge that gap and to address the needs of this wider audience of non-scholarly, English-speaking souls worldwide.

Finally, and very importantly, in trying to reach an audience, the faithful conveyance of the message cannot be sacrificed. The pious Muslim translator does not compromise the Word of God, of Allah, let alone try to rearrange it as those such as Dawood have done. Difficulties certainly arise when certain Qur'anic precepts may seem

\footnotetext{
$50 \quad$ Irving, xxi.

51 Irving, xxiv.

52 Alī, xiii.
} 
strange or unacceptable in the target culture. It may be tempting to soften the Qur'anic injunctions on women, for example, or even alter them to suit "politically correct" tenants of feminism that are particularly found in Western societies. A faithful rendering of the original message must override any cultural prejudices the translator may have or encounter. He must not let himself veer from the meaning in an over-eagerness to gain acceptance of his translation.

\section{A New English Translation-By Whom? For Whom?}

A translator of the Qur'àn may feel that his predecessors' efforts have been inadequate, but it is impossible to ignore the efforts of earlier scholars. All new translations owe a great deal to those published before. A translator may consciously calculate that he has a new, constructive approach or system for the project. He may also be looking for some personal reward in the form of money, a promotion or fame. However, the noblest reward for a Muslim translator would be to please God. Reward from Allah is indeed the best reward of all. On the other hand, the Muslim translator must always bear the full weight of responsibility for transmitting the true and accurate message. Any misunderstandings, errors, distortions or inaccuracies will fall directly upon his soul. He believes that he will be held fully accountable, and that serious misjudgments cannot be excused or blamed on the ignorance or the misinterpretation of his audience.

As one of the preparers of a new English Qur'ān translation, along with the late Dr. Maneh Hammad Al-Johani (d. 2002), this translator (1945-) is well aware of all the above factors and pitfalls associated with such a project. It was noted that many Qur'anic translations had been done by those whose first language was neither English nor Arabic, and many others were the result of the single efforts of those whose mother tongue was either English or Arabic. Still others were seen to be superficial revisions or collations of wellknown translations. The above perceptions became bases for the motivation behind this new co-effort by a native speaker of Arabic and a native speaker of English, both skilled in each other's languages and well-versed in Islam and Muslim culture.

Dr. Al-Johani and other propagators of Islam had long felt the need for a clear, concise translation of the Qur'ān, a translation that 
could be understood by most people who use English throughout the world. This required a faithful, accurate translation that not only could be easily understood by the young and others of limited education in English-speaking lands, but also by those for whom English was a second or third language. They needed a text unencumbered by the common Islamic terminology familiar to educated Muslims. As the primaryTA of this translation, Muslim and non-Muslim alike, was not a scholarly one, the range of vocabulary available to the learned reader was not assumed. Examples are words such as tawhid for monotheism, zakāh for the Islamic poor-tax and even salām for peace. ${ }^{53}$ Zakāh has consistently been given as "poortax." Its denotations and connotations, however, are better studied in a book than rendered in a phrase.

In a separate category is the Arabic word for God, Allāh. Almost without exception, pious Muslims prefer to use it over any other of His names that have existed in other languages. First, it is the most common name of God found in the Qur'ān. Second, it is the name God chose for Himself in the Qur'àn. As a result there is hardly a Muslim, or even a non-Muslim Arab, who does not use Allāh to the exclusion of a name in any other language. However, the vast, primary target audience of this translation was English-speaking and non-scholarly. Most were assumed to be non-Muslim and not know Allāh as God. If they knew the word Allāh at all, that audience might think it meant the God of the Muslims alone. God with a capital $g$ and no article is none other than Alläh, God and Creator of the Entire Universe. The primary target audience, then, determined the use of God for Allāh.

Wherever possible, when a more common word was available, the rarer word was avoided. Undesirable, too, was a style that hindered the understanding of an unsophisticated reader. The aim was not to imitate the inimitable style of the Qur'àn or to create a rival to the King James Version of the Bible in the English of the early $17^{\text {th }}$ century. In the translators' opinion, the message of the Qur'ān could not be conveyed by words that merely sounded or looked holy. The words had first to convey the clear meaning of

53 This section is based partially on the section, "Why Another Translation of the Qur'ān?" in Peachy and Al-Johani, vi-x. 
the words of the Qur'ann. For as discussed above, in addition to the widely acknowledged requirement that every Muslim make an attempt to understand the message, there is also the requirement that he convey it to others.

Although the primary audience was the literate, unsophisticated native speaker of English, there were also secondary target audiences of this translation. Arabic, Islamic terms were avoided in the hopes that, for Muslims whose primary literary language was English, the attempted concision and precision of words would provide, or at least permit, a deeper understanding of the message of the Qur'àn than those of earlier translations. An extensive vocabulary was forgone, but the translators hoped that scholars would find that this translation accommodated a range of interpretation more closely approximating the ranges of meaning to be found in the Qur'anic text. That is, the translators tried to reproduce the precise meaning of verses that were precise and to convey the extent of meaning in those verses that had been understood in more than one way by Muslim scholars. Great effort was taken to avoid the tendency observed in other works to translate commentary rather than the actual text of the Qur'àn. ${ }^{54}$

As explained above, an important goal of this work was to reach a much wider audience. However, the primary aim of all promoters of Islam and Muslim translators has been to deliver the message as faithfully as is humanly possible. The attempts at a general concision of expression, precision in translating verses of precise meaning, comprehensiveness in rendering verses of broad meaning, and avoidance of over-interpreting verses of unclear meaning were not always satisfactory.

\footnotetext{
54 A well-known example in this respect is the translation of Dr. Muhammad Taqiud-Dīn Al-Hilālī and Dr. Muhammad Mụ̣sin Khān, Translation of the Meanings of the Noble Qur'an in the English Language. (Ghakkhar District Gujranwala, Pakistan: Sethi Straw Board Mills (Conversion) LTD., 1974). The latest, improved version was edited by a committee of the King Fahd Complex for the Printing of the Holy Qur'ān, Medina, Kingdom of Saudi Arabia, in 1999. Yusuf Ali's work, The Holy Qur'an, English Translation of the Meanings and Commentary, (a recent edition is that of the KFCPHQ, Medina, Kingdom of Saudi Arabia, circa 1990), which is the base of Muhsin Khān and Hilālī's effort, is another, more successful example of the merging of Qur'ān and commentary translation.
} 
Peachy and Al-Johani had to consider also, nolens volens, a rather special and particularly restricted, secondary target audience. This audience included Islamic scholars, publishers and state organs in the country of publication, i.e. the Kingdom of Saudi Arabia. The two knew that any work on the Qur'ann, particularly commentaries and translations were sensitive materials for the Royal Saudi Government. It was an important factor motivating the collaboration of the two scholars. Al-Johani was a part of that State as a professor at King Saud University and then as an appointed member of the Consultative Council. Until his death, he was also the Secretary-General of WAMY, a non-governmental, charitable, Islamic organization. Both Peachy and Johani had hoped that Johani's knowledge and experience as well as his relations and connections with the Saudi State would help avoid bureaucratic mistakes. Unfortunately, his death had a negative impact in this area as well. The Royal Saudi Ministry of Information still has not issued the required permission for distribution of the text within the Kingdom itself. Thus, while the place of publication was the Kingdom, the distribution had to begin abroad.

\section{Conclusion}

Muslims have been given the duty to spread the message of the Glorious Qur'ān to the best of their ability. This message is universal and meant for all mankind, but as all mankind does not understand the clear, classical Arabic of the Qur'ann, the message must, in some way, be put in a form that all can comprehend. This provides a very strong answer as to why these attempts at translation must be made. The translation of any literary work, and most especially of the Qur'ān, requires a competency in both the language of the original work and that of the target audience. Thus, it is all the more important that those by whom it is translated and conveyed be competent, and that they possess the knowledge and skills required to do so. In addition, those for whom the translation is intended must be carefully considered. The language used must be that which they can easily understand. In this case, the message itself must take precedence over the style of the language, although the language should reflect contemporary usage and vocabulary. This is not always easy, and the translator must tackle many difficulties and decide how 
best to convey the message. There is not always a simple one-onone translation for every word or phrase, especially when trying to express Islamic and cultural concepts accurately. 